\title{
Hemihexaphyrazine and Thiadiazole Annulated Hemihexaphyrazine: A Theoretical Insight into Aromaticity and Energetics of Hydrogen Bonding
}

\author{
Arseniy A. Otlyotov, ${ }^{@ 1}$ Vladimir V. Veretennikov, Anton P. Merlyan, \\ Evgeny N. Ivanov, Yana E. Filippova, Yuriy A. Zhabanov, ${ }^{@ 2}$ and Mikhail K. Islyaikin ${ }^{\circledR 3}$ \\ Institute of Macroheterocycles, Ivanovo State University of Chemistry and Technology (ISUCT), 153000 Ivanovo, Russian \\ Federation \\ ${ }^{\circledR 1}$ Corresponding author_E-mail: arseney_otlyotov@mail.ru \\ ${ }^{\circledR 2}$ Corresponding authorE-mail: zhabanov@gmail.com \\ ${ }^{\circledR 3}$ Corresponding author E-mail: islyaikin@isuct.ru
}

\begin{abstract}
Seventeen tautomeric structures of hemihexaphyrazine were considered using DFT in B3LYP/pcseg-2 approximation. The tautomer of $D_{3 h}$ symmetry was found to be the most energetically favorable, and transformations into other tautomers are practically forbidden by high energy barriers (more than $50 \mathrm{~kJ} \cdot \mathrm{mol}^{-1}$ ). The energetics of hydrogen bonding was estimated by NBO and QTAIM calculations and the preferable $D_{3 h}$ tautomer turned out to possess the lowest total hydrogen bond stabilization energy, according to the results of the $\mathrm{NBO}$-analysis. Aromaticity of the $D_{3 h}$ and $C_{3 h}$ tautomers of hemihexaphyrazine and its thiadiazole annulated analogue was described with use of three popular descriptors: NICS, HOMA and FLU. Tautomeric preference and structural features of the both molecules were found to be very similar.
\end{abstract}

Keywords: Hemihexaphyrazine, aromaticity, hydrogen bonding, NBO-analysis, QTAIM.

\section{Гемигексафиразин и тиадиазол-аннелированный гемигексафиразин: теоретическое исследование ароматичности и энергетики водородных связей}

\author{
А. А. Отлётов, ${ }^{@ 1}$ В. В. Веретенников, А. П. Мерлян, Е. Н. Иванов, \\ Я. Е. Филиппова, Ю. А. Жабанов, ${ }^{\circledR 2}$ М. К. Исляйкин ${ }^{\circledR 3}$
}

НИИ Макрогетерочиклических соединений, Ивановский государственный химико-технологический университет, 153000 Иваново, Россия

@1E-mail: arseney_otlyotov@mail.ru

$@_{2}$ E-mail: zhabanov@gmail.com

@3E-mail: islyaikin@isuct.ru

\begin{abstract}
C помощью DFT расчетов в приближении B3LYP/pcseg-2 изучены семнадиать таутомеров гемигексафиразина. Таутомер симметрии $D_{3 h}$ является наиболее энергетически выгодным, причем его превращения в другие таутомеры практически невозможны из-за высоких энергетических барьеров (более 50 кДж/моль). Энергия водородных связей была оценена с помощью расчетов в приближениях NBO и QTAIM. Согласно результатам NBO-анализа, суммарная энергия внутримолекулярных водородных связей имеет наименьшее значение для наиболее энергетически выгодного $D_{3 h}$ таутомера молекуль. Ароматичность $D_{3 h} u C_{3 h}$ таутомеров гемигексафиразина и его тиадиазол-аннелированного аналога была описана с использованием трёх критериев ароматичности: NICS, НОMA и FLU. Согласно результатам расчётов, молекуль обнаруживают сходные тенденции в изменении суммарной энергии внутримолекулярных водородных связей и ароматичности.
\end{abstract}

Ключевые слова: Гемигексафиразин, ароматичность, водородная связь, NBO-анализ, QTAIM. 


\section{Introduction}

Investigations of the molecular structure and tautomeric preference of macroheterocyclic systems have been the subject of the many recent studies. ${ }^{[1-7]}$ Among a huge number of macrocycles, hemihexaphyrazins of ABABABtype attract a great interest due to their unusually high symmetrical structures, ${ }^{[4-6]}$ expanded coordination cavity with enormous potential in coordination chemistry ${ }^{[8-11]}$ and catalysis, ${ }^{[12]}$ and molecular level information storage. ${ }^{[6]}$ In our recent work ${ }^{[13]}$ a study of tautomeric preference and intramolecular hydrogen bonding was performed for the thiadiazole annulated hemihexaphyrazine (TDAHHp, Scheme 1). According to the results of the DFT calculations, TDAHНp was determined to have the single energetically favourable tautomer of $D_{3 \mathrm{~h}}$ symmetry, while the other structures were more than $39 \mathrm{~kJ} \cdot \mathrm{mol}^{-1}$ higher in energy. An attempt was made to explain this preference by the presence of six intramolecular hydrogen bonds $\mathrm{N}_{\mathrm{t}}$...H inside coordination cavity in the case of the $D_{3 \mathrm{~h}}$ structure, since all the other tautomers contained less than six bonds.

However, the calculations of the total hydrogen bond stabilization energy $\left(E_{\mathrm{HB}, \text { tot. }}\right)$ performed in the framework of the NBO-analysis of the electron density distribution drew the contrary picture: less number of stronger hydrogen bonds in the other tautomers provide their structures with larger stabilization energies as compared to the preferable $D_{3 \mathrm{~h}}$ structure. The calculations of $E_{\mathrm{HB}, \text { tot. }}$ with use of QTAIM approach resulted in the opposite trend: the $D_{3 \mathrm{~h}}$ structure of TDAHHp was found to possess the largest stabilization energy among the considered tautomers, however, the difference between the lowest and the largest $E_{\mathrm{HB}, \text { tot. }}$ values was 6 times less as compared to the quantity of same kind calculated from the NBO analysis. These contradictive results did not explain the pronounced preference of the $D_{3 \mathrm{~h}}$ structure.

This work expands our investigation of TDAНHр in two ways: the previously found contradiction between NBO and QTAIM estimations of hydrogen bond energies is examined for the analogous tautomers of the parent hemihexaphyrazine (HHp, Scheme 1) mac- rocycle, and another powerful factor that can influence the tautomeric preference, namely, aromaticity is assessed for both TDAHHp and HHp molecules.

\section{Computational details}

DFT calculations for 17 possible NH-tautomers of $\mathbf{H H p}$ were performed with use of Gaussian 09 program package. ${ }^{[14]}$ The calculations were carried out using B3LYP ${ }^{[15-17]}$ functional and pcseg- $2^{[18]}$ basis set $(\mathrm{C}, \mathrm{N}, \mathrm{H}, \mathrm{S})$ taken from the EMSL BSE library. Planar models of the tautomers (Figure S1) were optimized under $D_{3 \mathrm{~h}}$ (HHp), $C_{3 \mathrm{~h}}$ (3PT-1), $C_{2 \mathrm{~V}}$ (2PT-1, 2PT-7, 2PT-8) and $C_{\mathrm{S}}$ (1PT-1, 1PT-2, 1PT-3, 2PT-2, 2PT-3, 2PT-4, 2PT-5, 2PT-6, 2PT9, 3PT-2, 3PT-3, 3PT-4) symmetry constraints. Vibrational frequencies were calculated in the harmonic approximation for all the optimized structures. The abbreviations of the tautomers reflect "proton(s) transfer" (PT) from the main HHp structure, e.g., the structures 1PT-1 and 1PT-2 can be obtained from the main HHp structure by "migration" of one hydrogen from atom $\mathrm{N}$ of an isoindole fragment to atom $\mathrm{N}_{t}$ of a thiadiazole fragment, etc.

The search of transition states between the structures corresponding to local minima on the PES was performed using the Synchronous Transit-Guided Quasi-Newton (STQN) Method $^{[19]}$ requested by QST3 keyword.

The natural bond orbital (NBO) analysis was performed as it is implemented in Gaussian 09. ${ }^{[20]}$

Quantitative QTAIM (Quantum Theory of Atoms in Molecules) analysis was performed using AIMAll software package. ${ }^{[21]}$

Aromaticity of the main $D_{3 \mathrm{~h}}$-structures of $\mathbf{H H p}$, its thiadiazole annulated analogue (TDAHHp) and their 3PT-1 tautomers was estimated with use of NICS, ${ }^{[22]}$ HOMA $^{[23]}$ and FLU ${ }^{[24,25]}$ descriptors. NICS $(0)$ values were calculated at the centers of the cyclic fragments and NICS(1) - at points $1 \AA$ above the ring centers. The values of HOMA criterion were calculated for the optimized structures as proposed in the ref. ${ }^{[23]}$ FLU descriptors were estimated from the results of the AIM calculations according to the formulae proposed by E. Matito et al. ${ }^{[24]}$ It should be noted that the $\delta_{\text {ref }}(\mathrm{C}-\mathrm{S})=1.29$ was taken as $\delta(\mathrm{C}-\mathrm{S})$ in the aromatic thiophene molecule calculated at B3LYP/pcseg-2 level. The value of $\delta_{\text {ref }}(\mathrm{N}-\mathrm{S})=1.30$ was taken as $\delta(\mathrm{N}-\mathrm{S})$ in 1,2,5-thiadiazole calculated at the same level.

Molecular models were visualized with use of Chemcraft program. ${ }^{[26]}$

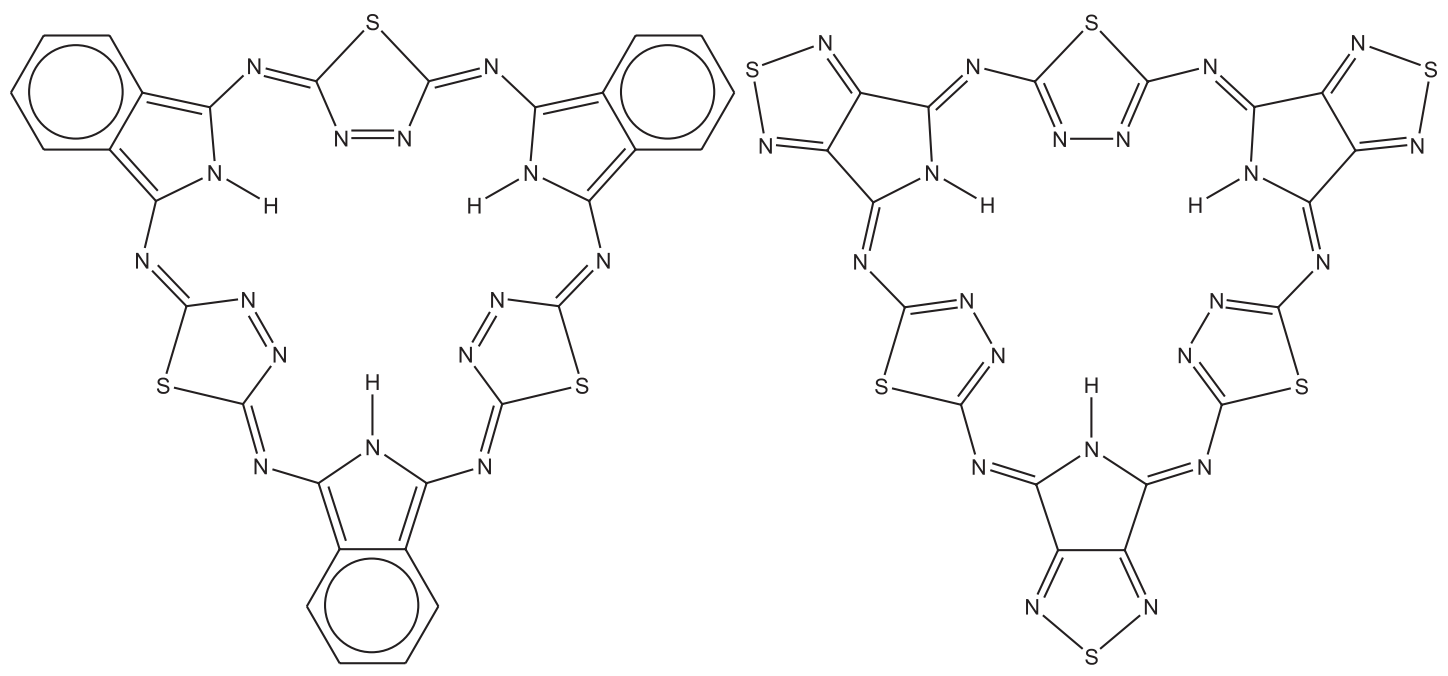

Scheme 1. Hemihexaphyrazine (HHp, left) and thiadiazole annulated hemihexaphyrazine (TDAHHp, right). 


\section{Results and Discussion}

NH-Tautomerism and Energetics of Hydrogen

Bonding in $\mathbf{H H p}$ and $\mathbf{T D} \boldsymbol{A H H p}$

According to the results of the calculations, the structure of HHp of $D_{3 \mathrm{~h}}$ symmetry corresponds to the global minimum on the PES. The local minima (1PT-1, 2PT-1, 2PT-3, 2PT-7, 3PT-1, 3PT-4, see Figure 1) are more than $45 \mathrm{~kJ} \cdot \mathrm{mol}^{-1}$ higher

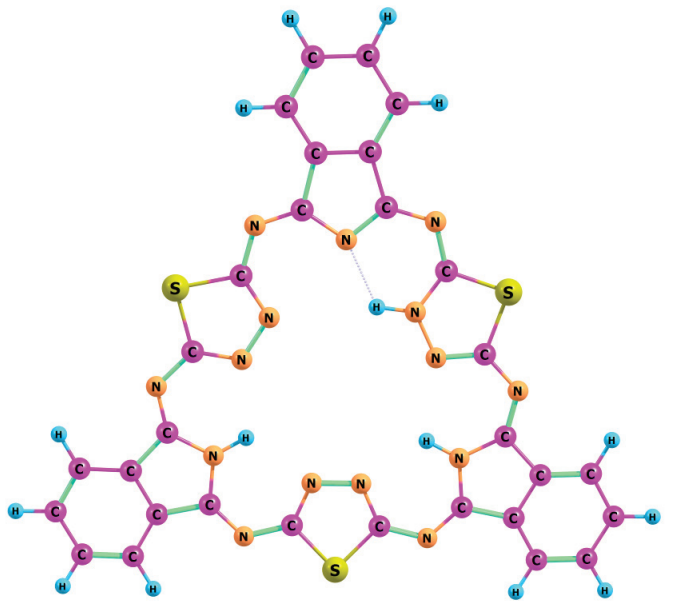

1PT-1 $(C), \Delta E=45.7 \mathrm{~kJ} \cdot \mathrm{mol}^{-1}$

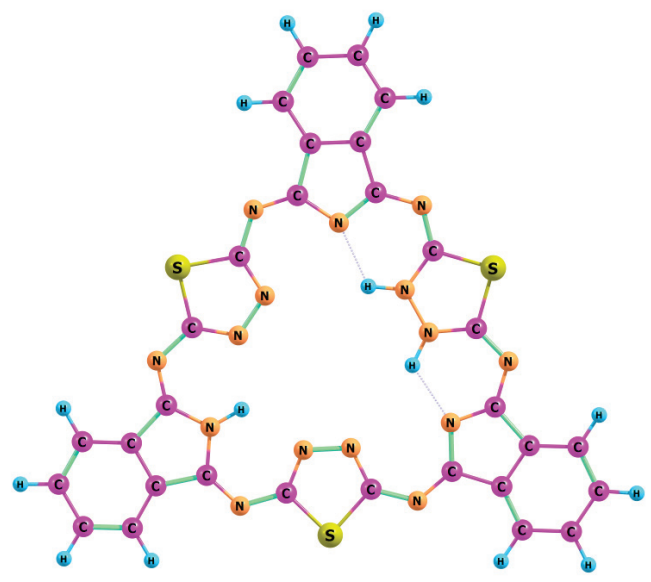

2PT-3 $\left(C_{\mathrm{s}}\right), \Delta E=81.5 \mathrm{~kJ} \cdot \mathrm{mol}^{-1}$

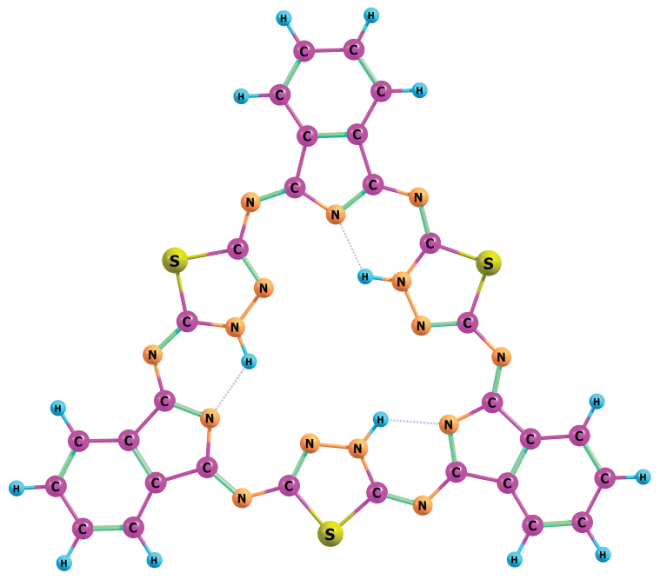

3PT-1 $\left(C_{3 \mathrm{~h}}\right), \Delta E=107.4 \mathrm{~kJ} \cdot \mathrm{mol}^{-1}$ in energy (see Table S1). Another NH-tautomers were found to correspond to saddle points on the PES.

Relative energies of the most energetically favorable tautomers of HHp demonstrate the similar trend as those previously reported for the TDAHHp molecule. ${ }^{[13]}$

The barriers were calculated by to be very high (more than $50 \mathrm{~kJ} \cdot \mathrm{mol}^{-1}$, Figure 2), therefore both $\mathbf{H H p}$ and TDAHHp should only adopt the lowest in energy $D_{3 \mathrm{~h}}$ structures.

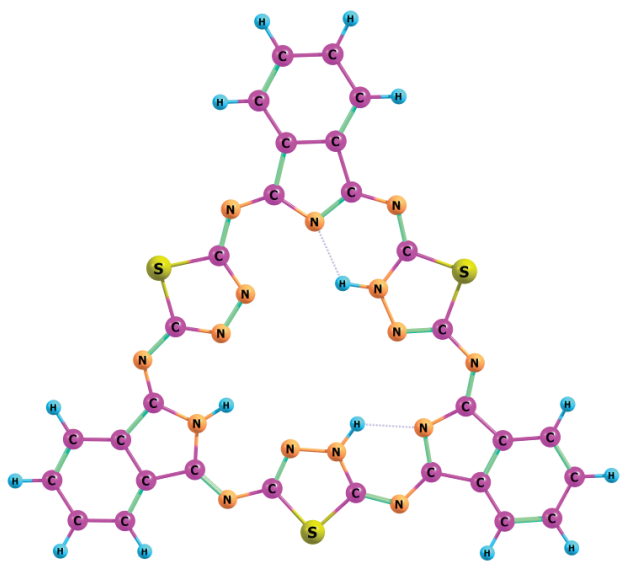

2PT-1 $\left(C_{2 \mathrm{v}}\right), \Delta E=141.0 \mathrm{~kJ} \cdot \mathrm{mol}^{-1}$

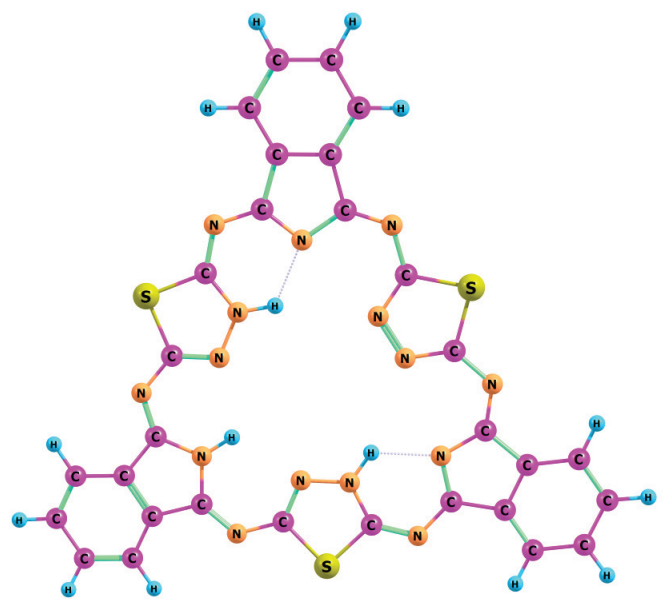

2PT-7 $\left(C_{2 \mathrm{v}}\right), \Delta E=97.9 \mathrm{~kJ} \cdot \mathrm{mol}^{-1}$

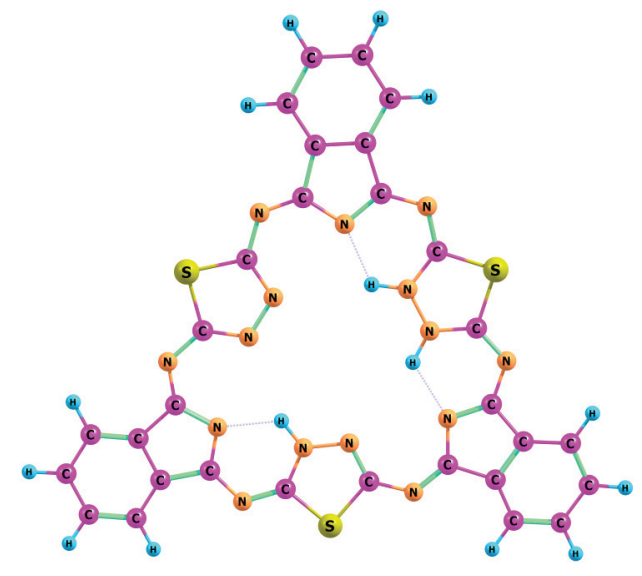

3PT-4 $\left(C_{\mathrm{s}}\right), \Delta E=182.1 \mathrm{~kJ} \cdot \mathrm{mol}^{-1}$

Figure 1. Structures of the tautomers of $\mathrm{HHp}$ corresponding to the local minima on the PES, and their energies relative to the $D_{3 \mathrm{~h}}$ structure (Scheme 1). 

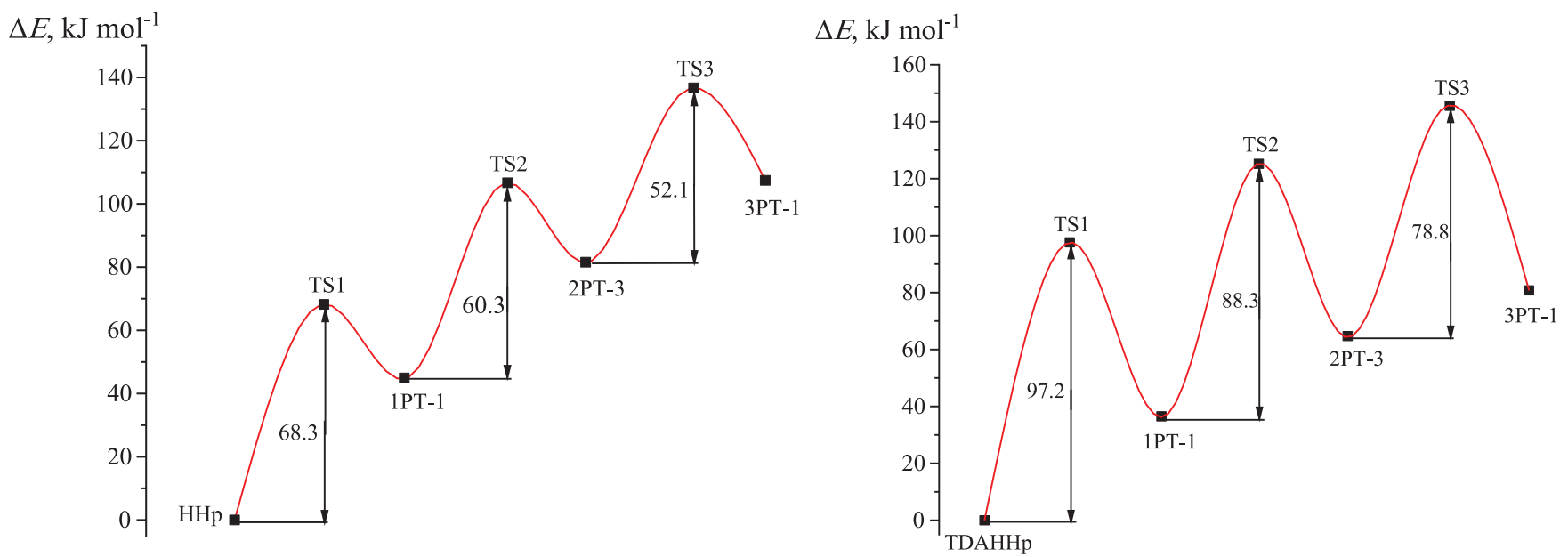

Figure 2. Energy barriers for the proton transfer processes in HHp and TDAHHp estimated from QST3 calculations.

The energies of the intramolecular hydrogen bonds were estimated based on the NBO-analysis as the energies of donor-acceptor interactions between the lone pairs (LPs) of the $\mathrm{N}_{t}$ atoms and $\sigma^{*}(\mathrm{~N}-\mathrm{H})$ antibonding orbitals. The total energy $E_{\text {sum }}^{(2)}\left[\mathrm{LP}(\mathrm{N}) \rightarrow \sigma^{*}(\mathrm{~N}-\mathrm{H})\right]$ was found to be the largest in the case of 3PT-1 tautomers of HHp and TDAHHp (see Table 1). Another possible way using AIM results to estimate the energy of a hydrogen bond was suggested by Espinosa et. al. ${ }^{[27]}$ They proposed an equation, connecting this energy with the potential energy density $V\left(\mathbf{r}_{\mathrm{CP}}\right)$ calculated at a bond critical point: $E_{\mathrm{HB}}=0.5 V\left(\mathbf{r}_{\mathrm{CP}}\right)$. The calculations for the series of the tautomers of $\mathbf{H H p}$ based on the results of QTAIM calculations demonstrated the opposite trend in the values of $E_{\mathrm{HB}}$ as compared to the NBO results. However, the difference in the total hydrogen bond energies between the main $D_{3 \mathrm{~h}}$ structure and 3PT-1 tautomer is much larger according to the NBO calculations as compared to QTAIM (see Figure 3). Therefore, hydrogen bonding is not responsible for the found preference of the $D_{3 \mathrm{~h}}$ structures of $\mathbf{H H p}$ and TDAHHp: three strong H-bonds in the 3PT-1 tautomers provide their structures with larger total stabilization energies as compared to six weak N...H contacts occurring in the most favourable $D_{3 \mathrm{~h}}$ tautomers. The trends shown in Figure 3 are similar for both HHp and TDAHHp. Therefore, the replacement of the benzene ring in HHp by thiadiazole ring (in TDAHHp) does not influence the interactions inside macrocyclic cavity.

\section{Macrocyclic Core of TDAHHp and HHp: Aromatic or Not?}

Pronounced stability of $D_{3 \mathrm{~h}}$ structures of TDAHHp and HHp might be supposed to be caused by the aromatic properties of their macocyclic core. In order to examine this hypothesis, we applied the well-known aromaticity criteria HOMA and NICS and the recently developed FLU descriptor to the tautomers with the smallest and the largest numbers of the intramolecular hydrogen bonds. The results of the calculations are listed in Table 2.

According to the results of the calculations, the values of the aromaticity indices HOMA, NICS and FLU calculated in the centers of the macrocycles do practically not depend on the nature of the annulated ring (either benzene in HHp, or thiadiazole in TDAHHp). However, aromaticity of the macrocycle increases in the case of 3PT-1 tautomer as compared to the main $D_{3 \mathrm{~h}}$ structures according to the values of all the descriptors examined. One can also note a decrease of aromaticity of a thiadiazole ring (thiadiazole A in the case of TDAHHp) in 3PT-1 tautomers as

Table 1. Relative energies of the tautomers of HHp and TDAHHp and total hydrogen bond stabilization energies estimated from NBO and QTAIM calculations.

\begin{tabular}{|c|c|c|c|c|}
\hline Model & ННр & 1PT-1 & 2PT-3 & 3PT-1 \\
\hline$\Delta E, \mathrm{~kJ} \cdot \mathrm{mol}^{-1}$ & 0 & 45.7 & 81.5 & 107.4 \\
\hline$E_{\text {sum }}^{(2)}\left[\mathrm{LP}(\mathrm{N}) \rightarrow \sigma^{*}(\mathrm{~N}-\mathrm{H})\right], \mathrm{kJ} \cdot \mathrm{mol}^{-1}$ & 97.7 & 117.1 & 141.8 & 160.8 \\
\hline$E_{\mathrm{HB}, \text { total }}, \mathrm{kJ} \cdot \mathrm{mol}^{-1}$ & 112.6 & 111.1 & 110.6 & 109.1 \\
\hline Model & ТDАННр & 1PT-1 & 2PT-3 & 3PT-1 \\
\hline$\Delta E, \mathrm{~kJ} \cdot \mathrm{mol}^{-1}$ & 0 & 39.2 & 68.8 & 88.7 \\
\hline$E_{\text {sum }}{ }^{(2)}\left[\mathrm{LP}(\mathrm{N}) \rightarrow \sigma^{*}(\mathrm{~N}-\mathrm{H})\right], \mathrm{kJ} \cdot \mathrm{mol}^{-1}$ & 92.6 & 106.1 & 125.5 & 138.8 \\
\hline$E_{\mathrm{HB}, \text { total }}, \mathrm{kJ} \cdot \mathrm{mol}^{-1}$ & 107.7 & 104.6 & 102.8 & 100.0 \\
\hline Number of $\mathrm{H}-$ bonds & 6 & 5 & 4 & 3 \\
\hline
\end{tabular}




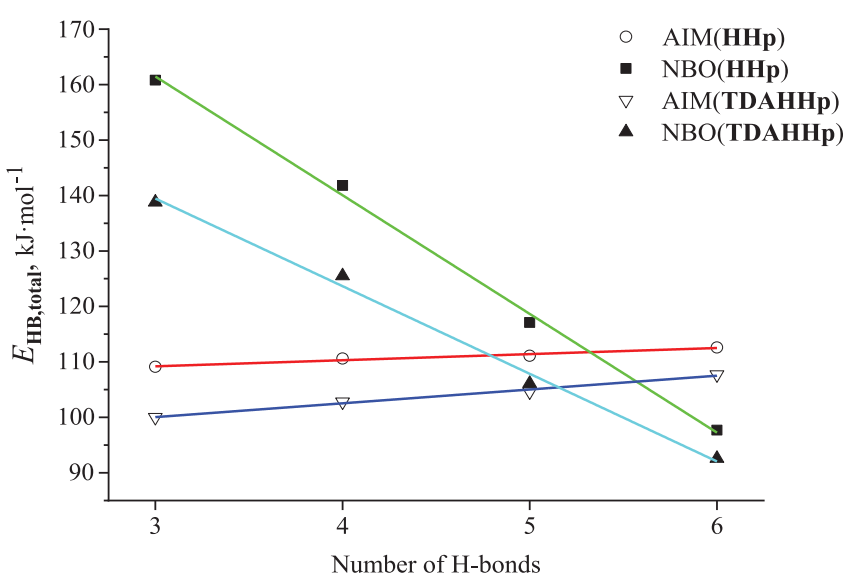

Figure 3. Trends in the total hydrogen bond stabilization energy in the series of tautomers of HHp and TDAHHp according to the NBO and QTAIM calculations. hydrogen atoms being bonded to the $\mathrm{N}$ atoms of the isoindole rings. The other tautomers are more than $45 \mathrm{~kJ} \cdot \mathrm{mol}^{-1}$ higher in energy and transitions between the tautomers in the gas phase were calculated to be practically forbidden by the large barriers. Interestingly, the total stabilization energy of the intramolecular hydrogen bonds, estimated from the NBO calculations, was found to be the lowest in the case of the most energetically favorable $D_{3 \mathrm{~h}}$ tautomer. Another reason of stabilization of the $D_{3 \mathrm{~h}}$ structure might be connected with its possible aromatic properties. However, according to the values of HOMA and FLU aromaticity descriptors, the structure of $C_{3 \mathrm{~h}}$ symmetry should possess more pronounced aromatic properties as compared to the main $D_{3 \mathrm{~h}}$ tautomer. At the same time, positive values of the NICS criterion calculated in the center of the macrocycle indicate the absence of aromaticity. The structural features were found to be the same for hemihexaphyrazine and its thiadiazole annulated analogue. Therefore, the replacement of the benzene ring in $\mathbf{H H p}$ by thiadiazole

Table 2. Aromaticity criteria NICS, HOMA and FLU for HHp and TDAHHp and their 3PT-1 tautomers.

\begin{tabular}{cccccccccc}
\hline & NICS(0) & NICS(1) & HOMA & FLU & & NICS $(0)$ & NICS(1) & HOMA & FLU \\
\hline $\begin{array}{c}\text { HHp } \\
\left(D_{3 \mathrm{~h}}\right)\end{array}$ & & & & & TDAHHp & & & & \\
Center & +1.37 & +0.83 & 0.864 & 0.022 & Center & +1.52 & +0.96 & 0.833 & 0.024 \\
Thiadiazole & -8.39 & -7.23 & 0.772 & 0.010 & Thiadiazole A & -8.68 & -7.60 & 0.801 & 0.009 \\
Pyrrole & +1.72 & -0.68 & 0.208 & 0.063 & Pyrrole & +4.38 & +0.04 & 0.167 & 0.073 \\
Benzene & -7.06 & -8.94 & 0.991 & 0.001 & Thiadiazole B & -11.04 & -10.43 & - & 0.008 \\
3PT-1 $\left(C_{3 \mathrm{~h}}\right)$ & & & & & 3PT-1 $\left(C_{3 \mathrm{~h}}\right)$ & & & & \\
Center & +1.10 & +0.78 & 0.934 & 0.012 & Center & +1.13 & +0.80 & 0.923 & 0.013 \\
Thiadiazole & -7.83 & -4.88 & 0.566 & 0.020 & Thiadiazole A & -8.09 & -5.18 & 0.716 & 0.019 \\
Pyrrole & +6.43 & +0.88 & 0.280 & 0.029 & Pyrrole & +9.09 & +1.21 & 0.047 & 0.058 \\
Benzene & -6.53 & -8.45 & 0.985 & 0.001 & Thiadiazole B & -9.59 & -9.43 & - & 0.010 \\
\hline
\end{tabular}

compared to the $D_{3 \mathrm{~h}}$ structures, that reflects its increased involvement into macrocyclic conjugation system. Experimental evidences of the non-aromatic character of НHp were found in. ${ }^{[7]}$

At the same time, the obtained results indicate a contradiction between NICS criterion, on the one side, and HOMA and FLU descriptors on the other, concerning aromaticity of the macrocyclic core in the considered tautomers of HHp and TDAHHp. Positive NICS values calculated in the centers of the macrocycles reflect the absence of aromaticity, while the values of HOMA and FLU are close to that of the aromatic compounds, especially in the case of 3PT-1 tautomers.

\section{Conclusions}

Tautomeric preference of hemihexaphyrazine was studied for the first time by DFT calculations. The structure corresponding to the global minimum on the PES possesses the structure of $D_{3 \mathrm{~h}}$ symmetry with three inner ring (in TDAHHp) does not influence the interactions inside macrocyclic cavity.

Acknowledgements. This work is supported by the Russian Science Foundation (grant 17-73-10198).

\section{References}

1. Strenalyuk T., Samdal S., Volden H.V. J. Phys. Chem. A 2008, 112, 4853-4860.

2. Stępień M., Latos-Grażyński L. Aromaticity in Heterocyclic Compounds. Berlin, Heidelberg: Springer Berlin Heidelberg, 2009. p. $83-153$.

3. Zakharov A.V., Stryapan M.G., Islyaikin M.K. J. Mol. Struct.: THEOCHEM 2009, 906, 56-62.

4. Zakharov A.V., Shlykov S.A., Danilova E.A., Krasnov A.V., Islyaikin M.K., Girichev G.V. Phys. Chem. Chem. Phys. 2009, $11,8570-8579$.

5. Zhabanov Y.A., Zakharov A.V., Shlykov S.A., Trukhina O.N., Danilova E.A., Koifman O.I., Islyaikin M.K. J. Porphyrins Phthalocyanines 2013, 17, 220-228. 
6. Cirera B., Trukhina O., Björk J., Bottari G., RodríguezFernández J., Martin-Jimenez A., Islyaikin M.K., Otero R., Gallego J.M., Miranda R., Torres T., Ecija D. J. Am. Chem. Soc. 2017, 139, 14129-14136.

7. Trukhina O.N., Rodríguez-Morgade M.S., Wolfrum S., Caballero E., Snejko N., Danilova E.A., Gutiérrez-Puebla E., Islyaikin M.K., Guldi D.M., Torres T. J. Am. Chem. Soc. 2010, 132, 12991-12999.

8. Ivanov E.N., Trukhina O.N., Koifman O.I., Islyaikin M.K. Macroheterocycles 2016, 9, 225-229.

9. Lomova T.N., Filatov M.S., Islyaikin M.K. J. Porphyrins Phthalocyanines 2017, 21, 135-143.

10. Lomova T.N., Mozhzhukhina E.G., Danilova E.A., Islyaikin M.K. Russ. J. Coord. Chem. 2006, 32, 837-840.

11. Lomova T.N., Suslova E.E., Danilova E.A., Islyaikin M.K. Russ. J. Phys. Chem. 2005, 79, 201-206.

12. Zhang W., Sun S., Yang L., Lu C., He Y., Zhang C., Cai M., Yao Y., Zhang F., Zhuang X. J. Colloid Interface Sci. 2018, 516, 9-15.

13. Otlyotov A.A., Merlyan A.P., Veretennikov V.V., Pogonin A.E., Ivanov E.N., Filippova Y.E., Zhabanov Y.A., Islyaikin M.K. Macroheterocycles 2018, 11, 67-72.

14. Frisch M.J., Trucks G.W., Schlegel H.B., et al. Gaussian 09, Revision D.01. Gaussian, Inc., Wallingford CT, 2016.
15. Becke A.D. J. Chem. Phys. 1993, 98, 5648-5652.

16. Lee C., Yang W., Parr R.G. Phys. Rev. B. 1988, 37, 785789.

17. Vosko S.H., Wilk L., Nusair M. Can. J. Phys. 1980, 58, 1200-1211.

18. Jensen F. J. Chem. Theory Comput. 2014, 10, 1074-1085.

19. Peng C., Bernhard S.H. Isr. J. Chem. 1993, 33, 449-454.

20. Glendening E.D., Reed A.E., Carpenter J.E., Weinhold F. NBO Version 3.1.

21. AIMAll Version 16.01.09. Todd A. Keith, TK Gristmill Software, Overland Park KS, USA, 2017. (aim.tkgristmill.com).

22. Chen Z., Wannere C.S., Corminboeuf C., Puchta R., Schleyer P.R. Chem. Rev. 2005, 105, 3842-3888.

23. Krygowski T.M., Cyrański M.K. Chem. Rev. 2001, 101, $1385-1420$.

24. Matito E., Duran M., Solà M. J. Chem. Phys. 2004, 122, 014109.

25. Matito E., Duran M., Solà M. J. Chem. Phys. 2006, 125, 059901.

26. Zhurko G.A. Chemcraft - Graphical Program for Visualization of Quantum Chemistry Computations. https://chemcraftprog.com.

27. Espinosa E., Molins E., Lecomte C. Chem. Phys. Lett. 1998, $285,170-173$. 